\title{
Influence of Negotiation Dispute Resolution Mechanism on Sustainable Conflict Resolution in Bungoma County, Kenya
}

\author{
Atemi Amele Justin \\ P.O Box 1087, Bungoma, Kenya
}

\begin{abstract}
As noted by empirical evidence, negotiation is a key approach to the peaceful resolution of dispute and conflicts that may arise between the parties. It is also within the reach and control of parties like communication and collaboration because there are no third parties involved. Thus, negotiation is a direct process of dialogue and discussion taking place between at least two parties who are faced with a conflict situation or dispute. Both parties come to the realization that they have a problem, and both are aware that by talking to each other, they can find a solution to the problem. The purpose of this study was to assess the influence of utilization of alternative dispute resolution mechanisms by leaders on sustainable conflict resolution in Bungoma County, Kenya. The study focused on identifying the various types of conflicts in Lwandanyi, Webuye and Cheptais Sub-Counties and the factors influencing the adoption of Alternative Dispute Resolution Mechanisms with specific focus on negotiation . The specific objective of the study was to examine the influence of negotiation dispute resolution mechanism on sustainable conflict resolution in Bungoma County, Kenya. The sample size was comprised of grass root leaders. Simple random sampling and stratified random sampling methods were used to pick the required sample size for the study from the targeted population. The required data was collected using questionaire and interview schedules. The study found that leaders in Bungoma County appreciate and make use of ADR mechanisms in conflict resolution. Mediation mechanism was commonly cited as being used by leaders in addressing various forms of conflict. The study also found that land disputes are the commonest of all conflicts. This was attributed to historical land injustices especially in Mt. Elgon region where politicization of land allocations in the former white settler farms has led to long standing conflict between the Bukusu and the Sabaot communities. The study also revealed that most land disputes were arising due to lack of land ownership documents and rampant corruption at the lands' ministry was blamed for this state of affairs. Based on the study findings, it was recommended that the National and County governments take decisive action to address the land grievances of the Sabaot community to stop the inter clan fighting and leaders be trained and equipped with skills and competencies necessary for conflict resolution.
\end{abstract}

Keywords: Negotiation, Dispute Resolution Mechanism, Sustainable Conflict Resolution

DOI: $10.7176 /$ JLPG/111-07

Publication date:July $31^{\text {st }} 2021$

\subsection{Background of the Study}

According to conflict theorists (Fisher, 2000) there are several sources of disputes including economic, value and power. Economic dispute involves competing motives to attain scarce resources. Each party wants to get the most that it can to maximize net gains. Value disputes involve incompatibility in ways of life, ideologies the preferences, principles and practices that people believe in. Power dispute occurs when each party wishes to maintain or maximize the amount of influence that it exerts in the relationship and the social setting. Power conflict occurs between individuals, groups or nations.

Over the last decade courts have developed rules that require parties to try Alternative Dispute Resolution mechanisms, usually mediation, before trial. Mandatory Alternative Dispute Resolution has become popular because it helps unclog the court system and because most cases can settle once the parties have undertaken discovery and understand what evidence exists. Uwazie (2011) however observed that despite numerous attempts at modernization, many African countries are still struggling to establish functional, timely, and trusted judicial systems. Most courts in Africa are fraught with systemic problems, such as antiquated structures. Countless judges still take notes by hand, as there are no stenographers. Re-cords are archived manually and a reliable computer in an African court is rare, especially at the magistrate courts that handle most cases. Many African citizens have lost faith in the ability of their nations' courts to provide timely or just closure to their grievances (Liebmann, 2000).

\subsubsection{Alternative Dispute Resolution}

Dependent on the intensity of the disagreement the dispute may gradually become a confrontation and finally a conflict. Dispute resolution can occur through three ways; negotiated outcome, where the parties concerned sort out things themselves: mediated outcome, where the parties use the services of an independent mediator to help them arrive at their own agreement and an arbitrated or adjudicated outcome, where an independent arbitrator or 
court determines how the dispute is to be resolved and makes a binding decision or order to this effect (Algert \& Watson, 2002).

Alternative Dispute Resolution (ADR) is the general name given to a variety of procedures available to parties in civil cases to resolve their disputes before a formal trial (Lambert and Myers, 1999). Alternative Dispute Resolution refers to processes for resolving disputes other than litigation. Alternative dispute resolution (ADR) mechanisms have existed for thousands of years. Alternative dispute resolution (ADR) refers to any process or collection of processes established to resolve disputes without trial or violence. The term ADR is often used to refer to a broad category of ADR processes such as negotiation, conciliation, mediation, settlement conferences, arbitration, consensus building, and community conferencing.

The primary motivations for ADR are to save money and control risk. Preparing for trial is extremely expensive, and parties can save money if they can resolve the case without having to incur the expense of trial preparation (Barrett \& Barrett, 2004). Also, when parties settle cases, they have some control over the outcome of the case in that they can negotiate for terms of the settlement. If a lawsuit goes to trial, the outcome of the case is left entirely in the hands of the judge or jury. Parties cannot control the risk of losing at trial. ADR gives parties a chance to control that risk. In some cases, privacy or confidentiality may be a factor. Most litigants think of ADR as private, and thus, if they seek secrecy, they may be motivated to try ADR.

Deferent types of Alternative Dispute Resolution include arbitration, negotiation, mediation, adjudication, family group conferences, expert determination and case evaluation. In mediation, a neutral third party helps the parties come to an agreement about how to resolve the case (Barrett, \& Barrett, 2004). The mediator has no authority to impose a solution on the parties. Instead, he goes back and forth between sides to help them come to an understanding about how the case could be resolved to their mutual satisfaction. A mediator can be helpful in helping parties evaluate their case realistically, as the mediator can point out which facts or arguments he believes or rejects (Barrett, \& Barrett, 2004). When courts order parties to try ADR, they most often order mediation. Non-mediated settlement is the process where the parties negotiate with each other without the help of a third party to come to a mutually satisfactory resolution of the case. This process is not ordered or overseen by a court and, therefore, is a private, rather than public, process.

The idea of Alternative Dispute Resolution (ADR) is about the search for and application of "nonconventional" peaceful means of settling disputes and resolving conflict situations using the least expensive methods, and in ways that satisfy the parties, as well as ways that preserve relationship diplomatically after a settlement might have been reached by the two parties (Hornby, 2006). ADR is specially meant to serve as an alternative to the official or conventional means of settling disputes, mainly through litigation and the courts, but with a preference for non-violence.

\subsubsection{Bungoma County}

Over the years Bungoma County has witnessed numerous conflicts ranging from land clashes in the Mt Elgon region, political violence linked to electoral processes, domestic violence, conflicts related to business transactions as well as labor unrest just to mention but a few. Investigation of the influence of the utility component of Alternative Dispute Resolution strategies will help inform sustainability of conflict resolution efforts (Chesi, 2012). Also, land conflicts has affected Mt. Elgon District in Bungoma county of Kenya. These land conflicts have had far reaching negative effects on the certainty of land markets, tenure and food security, economic production and reduction of poverty. Often, the land conflicts lead to; civil strife, loss of lives, population displacement, destruction of property and international humanitarian crisis (Chesi, 2012).

\subsection{Statement of the problem}

Without timely, accessible, affordable, and trusted mechanisms to resolve differences, localized disagreements or crimes can degenerate into broader conflict (Algert, 1996). This contributes to cultures of violence and vigilante justice. There are recurrent conflicts despite efforts being put in place to address such conflict. The court systems are overwhelmed by a backlog of cases and have systemic challenges being brought about by corruption, poor infrastructure and inaccessibility that work to kill their efficiency. The choice of a good alternative dispute resolution strategy is a difficult task, because a lot of physical and mental energy is required (David, 2006).

It is apparent that the success of a functional alternative dispute resolution strategy depends on good application using appropriate method which can subsequently motivate parties in dispute in their various communities. Lack of good alternative dispute resolution strategy by a trained individual in our community and institution can lead to inappropriate behavior and frustration. In making choice of alternative dispute resolution strategies communities are faced with the challenges of selecting the method suitable for achieving non (David, 2006).

Sustainable conflict resolution still remains a major challenge in Kenya and beyond. As noted by Murungi (1995), numerous conflict resolutions have been attempted, but none of them seems sustainable in creating an atmosphere for peace, security and inter-ethnic. Disputes keep recurring sometimes with greater intensity leading 
to widespread loss of life and destruction of property. This is despite the litigation processes in court systems and other alternative efforts being expended in addressing conflict. There is a disconnect between sustainable conflict resolution and the numerous efforts being put to use. No study had been done on the influence of negotiation dispute resolution mechanism on sustainable conflict resolution in Kenya hence a research gap. This study therefore sought to investigate the influence of negotiation dispute resolution mechanism on sustainable conflict resolution in Bungoma County, Kenya.

\subsection{Purpose of the Study}

The purpose of the study was to assess the influence of utilization of alternative dispute resolution mechanisms by leaders on sustainable conflict resolution in Bungoma county, Kenya.

\subsection{Objective of the study}

The specific objective of the study was;

To assess the influence of negotiation dispute resolution mechanism on sustainable conflict resolution in Bungoma County, Kenya

\subsection{Research Question}

The study sought to answer the following question;

What is the effect of negotiation dispute resolution mechanism on sustainable conflict resolution in Bungoma County Kenya?

\subsection{Significance of the Study}

This research is vital to the conflict resolution teams in Bungoma County because it provides an insight on the utilization of alternative dispute resolution mechanisms by leaders on sustainable conflict resolution. The teams will be able acquire knowledge on the best approach to conflict resolution.

The results of this research are important to the Government of Kenya in the development of rules and procedures of solving conflicts arising within the country. Through the findings of this study, the policy makers can learn various ways in which they may need to handle conflict resolution and hence come up with policies that lead to sustainable conflict management and resolution.

The results of this study will greatly benefit the victims of conflicts in Bungoma County. It will increase awareness on the benefits of embracing Alternative Dispute Resolution Mechanisms and contribute to quick, timely and affordable administration of justice.

Future researchers will also be able to use the research findings as a benchmark to their research on conflict resolution. In addition, the findings of this study will serve as a source of reference in future research. The study has also suggested other areas where future researchers can further their knowledge.

\subsection{Literature Review}

This section discusses past studies on utilization of negotiation dispute resolution mechanisms by leaders and how it influences sustainable conflict resolution.

\subsubsection{Empirical Review}

According to Uwazie (2011) the notion of ADR fits comfortably within traditional concepts of African justice, particularly its core value of reconciliation. Pioneering ADR projects in Ghana, Ethiopia and Nigeria have generated positive results and illustrate the suitability of ADR in African contexts. Under these arrangements, ADR was used as the default resolution method. Formal court litigation, or instances where the judge actually judges, are reserved for cases of constitutional or legal interpretation, where there is a need to set precedence, in cases with major public policy implications, or as a last resort after ADR has been tried.

\subsubsection{Negotiation Dispute Resolution Mechanism}

Negotiation is a process in which two or more participants attempt to reach a joint decision on matters of common concern in situations where they are in actual or potential disagreement or conflict (Fisher, Ury and Patton 1991). Negotiation is any form of communication between two or more people for the purpose of arriving at a mutually agreeable solution. According to Fisher and Ury, (2011) prostrates that negotiation is a basic means of getting what you want from others. It is a back and forth communication designed to reach an agreement. In Negotiation, representatives of disputing parties often called negotiators meet to work with or against each other for their own position or pre-determined, desired outcome. Often formal negotiation proceedings take place between groups of people rather than individuals, and the list of tactics that negotiators may use is long and varied.

As noted by Umunadi (2011), negotiation is a key approach to the peaceful resolution of dispute and conflicts that may arise between the parties. It is also within the reach and control of parties like communication and collaboration because there are no third parties involved. Thus, negotiation is a direct process of dialogue 
and discussion taking place between at least two parties who are faced with a conflict situation or dispute. Both parties come to the realization that they have a problem, and both are aware that by talking to each other, they can find a solution to the problem. The benefits of compromised solution, it is believed to outweigh the losses arising from refusal to negotiate (Umunadi, 2011). In negotiation, there must be communication between two or more people intended to gain understanding, to produce agreement, to bargain between individual involved in a conflict or dispute.

Negotiation typically takes place during the early stages of conflict when communication between parties is cordial and good or at the de-escalation point when communication has been restored (Chikwe, 2011). There are two types of negotiation. We have the positional negotiation and the collaborative negotiation. The first type of negotiation is based on the aggressive pursuit of interest by parties, and is typically adversarial and competitive. Parties make demands that are inconsiderate of the interest and needs of others, and this makes it difficult for this interest to be met. Parties may also perceive themselves to be in competition. The desire will be to win, instead of working towards a mutually beneficial outcome. Thus, the demands of one party can be met only to the detriment of the other. Parties tend to stubbornly adhere to their positions and one side seems to dominate the negotiation. It can break down easily (Chikwe, 2011).

Fisher and Ury (2011) identify negotiation as the most used form of dispute resolution because of its vast applicability within the home and community. In a negotiation the disputants may represent themselves or they may be represented by agents and whatever the case, whether they are represented or not represented, they have control over the negotiation process. Even though negotiations can be time consuming and mentally taxing, they are usually most fruitful in the end, for there is the likelihood of a win- win situation, where both parties leave the table with something better than what they came with (Mnookin et al, 2000).

\subsubsection{Theoretical framework}

Various theorists have come up with theories on dispute resolution. The theories adopted by this study include theory of process pluralism, theory of conflict and General Theory on Conflicts and Disputes. Theory of process pluralism points out that different kinds of matters may require different kinds of procedures or ways of dealing with the underlying conflict (Ralf, 1958) theory of conflict attempts to understand the different sources of conflict, the dynamics of how conflict develops, escalates or declines, and how conflict can be managed, reduced or resolved. Conflict theory tries to explain the types of conflicts that exist and whether they are productive or destructive and then goes on to attempt to explain the ways in which conflict proceeds or is structured and how it can be managed or resolved. The General Theory on Conflicts and Disputes assigns disputes to transitional and mature democracies and conflicts to authoritarian regimes (Otomar and Wehr, 2001). The First Premise of the General Theory is that there are no conflicts in democratic society, only disputes. The Second Premise is that in authoritarian regimes there are only conflicts and politicized systems of settlement, not disputes. The Third Premise is that in international relations, national states can transform conflicts into disputes. Conflicts are those issues that lack a legitimate, reliable, transparent, non-arbitrary forum for the peaceful settlement of differences (Otomar and Wehr, 2001). Disputes, conversely, are pre described as having recognized forums for their expression and resolution that meet the above criteria. In short, conflicts lack a viable containe" for the routine management of differences. A mature theory of dispute-resolution must encompass all institutions and processes - whether legal or non-legal, formal or informal, contemporary or customary - to further the end of settling disputes by smoothing away discords.

\subsection{Research Methodology}

This study adopted a descriptive research design. As noted by Cooper and Schindler (2000) descriptive research design are concerned with addressing the particular characteristics of a specific population of subjects, either at a fixed point in time or at varying times for comparative purposes. As noted by Gill and Johnson (2002), descriptive research design describes characteristics associated with the subject population. By using descriptive research design, the study was able to establish the how of the phenomenon under investigation. The target population of this study comprised of the dispute resolution leaders in Bungoma county. These are Members of County Assembly (MCA), religious leaders, County Commissioners, local chiefs and their assistants, village and clan elders, representatives of aid agencies, representatives of civil society groups, women leaders and leaders of the youth. These leaders were selected because of the role they play in dispute resolution.

The study selected a representative sample of 90 from the target population. Use of a sample enables the study to save cost and time. According to Pamela L.A \& Robert B.S (1995) experienced researchers regard a sample of 100 respondents as the minimum sample size and 1000 as the maximum sample size for large populations. They note that it is seldom necessary to sample more than 10 percent of the population to obtain adequate confidence.

The study used purposive sampling and simple random sampling to select a sample from the target population. Purposive sampling is a method in which elements are chosen based on purpose of the study. In this study purposive sampling was used to pick three Sub-Counties namely; Webuye, Cheptais and Lwandanyi 
because they are conflict flash points. Simple random was used to randomly sample the leaders in each of the selected Divisions. According to Mugenda and Mugenda (2003), simple random sampling is a sampling technique designed to ensure that every unit of a population has equal chances of being selected in the population. By use of simple random sampling in this study, a representative sample was obtained.

The data collection instruments that were used in this study are questionnaires and checklist of specific questions that were posed to key informants. As noted by Mugenda and Mugenda(1999), questionaires are appropriate for use when the target population is educated and knowledgeble. The questionaires were chosen for data collection in this study since the population of the study is well educated and also the questionaires save on cost and time. The questionnaire designed in this study comprises of two sections. The first part includes the demographic characteristics questions designed to determine the profile of the respondents while part two deals with the identified factors. The questionnaire has both open and close ended questions. The closed ended questions make use of a five point Likert scale where respondents were required to fill according to their level of agreement with the statements. The unstructured questions were used to encourage the respondents to give an indepth response where close ended questions are limiting.

A pilot study was conducted to test for clarity and understanding of questions and also to find out whether the questions yield the answers expected. The researcher selected a pilot group of 5 individuals from the target population.

The study used both face and content validity to ascertain the validity of the questionnaires. Content validity was employed by this study as a measure of the degree to which data collected using a particular instrument represents a specific domain or content of a particular concept.

Reliability was assessed using the split half reliability method. Reliability is said to be stable if it gives consistent results with repeated measurements of the same object with the same instrument. The degree of stability is determined by comparing the results of repeated measurements. The split half method involves scoring two-halves of a test separately for each person and then calculating a correlation coefficient for the two sets of scores. The researcher split the instrument into two halves. The researcher got a coefficient of 0.70 which implies that there is a high degree of data reliability.

Kothari (2004) views data analysis as the whole process, which starts immediately after data collection and ends at the point of interpretation and processing of results. The quantitative data collected using questionnaires and interview schedules will be inspected for completeness, and analysed using Statistical Package for Social Sciences (SPSS v. 21.0). The results were presented in form of tables and graphs.

\subsection{Findings}

Research findings are presented in this section.

\subsubsection{Questionnaire return rate}

Out of 90 questionaires administered to 90 leaders in three sub counties of the larger Bungoma County, 85 were returned making questionaire return rate to be $94 \%$.

\subsubsection{Demographic information of the respondents}

This study sought information from male and female leaders of diverse age groups. This was aimed at ensuring that all leaders regardless of the age participated in the study.

\section{Table 1: Age of the respondents}

\section{Frequency Percent}

\begin{tabular}{lll}
\hline $25-35$ & 6 & 6.7 \\
$35-45$ & 26 & 28.9 \\
$45-55$ & 36 & 40.0 \\
$55-65$ & 21 & 23.3 \\
65 and older & 1 & 1.1 \\
& & \\
\hline Total & $\mathbf{9 0}$ & $\mathbf{1 0 0 . 0}$
\end{tabular}

The Table shows that $40 \%$ of the respondents were aged between $46-55$ years and that those aged between 36-45 years accounted for $28.9 \%$ of those interviewed. Those aged between $26-35$ years accounted for $6.7 \%$ while those between $56-65$ years stood at $23.3 \%$ The leaders who indicated that they were 65 years and above stood at $1.1 \%$ of the entire sample.

In terms of gender, $86.7 \%$ of the interviewed were men while $13.3 \%$ were women. In Luhya ,Teso and Saboat cultures women have not been readily accepted as capable leaders and have therefore been largely excluded from grass root leadership. Most village and clan elders are men hence the small number of women 
respondents. It is vital to note that the 2010 constitution gives both men and women equal opportunity in all spheres of social,political and economic being of our country. Therefore nobody should be discriminated or denied leadership opportunities on account of their gender. Women must rise to challenge these dicriminatory tendencies and play an active role in the leadership of their communities.

Table 2: Gender of the respondents

\begin{tabular}{llll}
\hline & & Frequency & Percent \\
\hline \multirow{3}{*}{ Valid } & Male & 78 & 86.7 \\
& Female & 12 & 13.3 \\
\hline & Total & $\mathbf{9 0}$ & $\mathbf{1 0 0 . 0}$
\end{tabular}

The respondents were asked to indicate their marital status, this was aimed at establishing whether marital status has a bearing on whether an individual is given leadership roles or not including conflict resolution.

Table 3: Marital status of the respondents

\begin{tabular}{llll}
\hline & & & Percent \\
& & Frequency & \\
\hline Valid & Married & 86 & 95.6 \\
& Single & 4 & 4.4 \\
\hline & Total & $\mathbf{9 0}$ & $\mathbf{1 0 0 . 0}$ \\
\hline
\end{tabular}

This study indicates that $95.6 \%$ the respondents are married while a mere $4.4 \%$ are single an indication that the local communities place value on family life and thus require their leaders to be marry before taking on leadership roles. This however, needs to change so that leadership is not pegged on marital status. It is discriminatory and unconstitutional

The respondents were asked to indicate their level of education, this was aimed at establishing whether education is a factor that hinders people from executing their leadership responsibilities including conflict resolution.

Table 4: Education of the respondents

\begin{tabular}{llll}
\hline & & Frequency & Percent \\
\hline \multirow{4}{*}{ Valid } & .00 & 1 & 1.1 \\
& Primary & 3 & 3.3 \\
& Secondary & 43 & 47.8 \\
& Tertiary & 33 & 36.7 \\
& University & 10 & 11.1 \\
\hline & & & $\mathbf{1 0 0 . 0}$
\end{tabular}

This study indicates that literacy levels among leaders in Bungoma County is high with $47.8 \%$ of the sampled leaders having attained secondary education,36.7\% had gone through tertiary institutions while holders of university degrees stood at $11.1 \%$. This therefore shows that the leaders have the requisite education and capacity to execute their functions including conflict resolution.

The question on whether the leaders were born and raised in their area of jurisdiction or they immigrated in to the area was also posed to the respondents. This was aimed at ensuring that the respondents understand the area they work in and the conflict issues at hand. $77.8 \%$ of the respondents said they were born and raised in their areas of jurisdiction. $15.6 \%$ of the respondents migrated into their current areas of residence while $2.2 \%$ of the sampled respondents were born in their areas of residence but were raised elsewhere. This is a clear indication that most of the sampled leaders know their areas well and have a grasp of the issues that cause conflict. 
From the study it was also established that $80 \%$ of the respondents have lived in their areas of jurisdiction all their lives while $11.1 \%$ indicated that they had lived in their areas of residence for Ten years or more. Only $7.8 \%$ of the responding leaders said they had lived in their areas for more less than five years. The length time lived in area has a bearing on a person's understanding of not just the area and its people but also the issues affecting them.

This question was posed to respondents with a view to establish whether or not they had worked in the public sector as government employees. Experience in the public sector especially in volatile areas gives an officer opportunity to handle and manage conflict. It affords such officers an opportunity to understand conflict resolution including alternative dispute resolution mechanisms. This experience works to equip the officers with knowledge and skills in the execution of their responsibilities to the public.

As shown in Table 5, 50\% of the respondents reported that they have never worked in the public sector as government employees while $44.4 \%$ reported to have worked in the public sector. The $50 \%$ however explained that they are village and clan elders who work alongside public servants especially chiefs and County Commissioners. Five respondents did not answer this question.

Table 5: Whether or not leader had worked in public service

\begin{tabular}{llll} 
& & Frequency & Percent \\
\cline { 3 - 4 } & & & 3.3 \\
\multirow{4}{*}{ Valid } & Yes & 3 & 44.4 \\
& No & 40 & 50.0 \\
& 7.00 & 25 & 2.2 \\
\hline & Total & $\mathbf{9 0}$ & $\mathbf{1 0 0 . 0}$
\end{tabular}

The dominant tribes in Bungoma Countyy are the Bukusu and the Sabaot accounting for $70 \%$ and $24 \%$ of the County population respectively. The Kikuyu,Teso,Tachoni and other tribes account for only $6 \%$ of the County population. This percentages explain the antagonism between the Bukusu and Saboat over land ,distribution of jobs and development resources.

In Lwandanyi and Cheptais Sub-Counties,this conflict is pronounced because of these two dominant tribes.The Saboats mainly inhabit the Cheptais area and the greater Mt. Elgon. The Saboat accuse the Bukusu of dominating them by taking most of the political and state leadership positions because of their superior population numbers. This fights led to the creation of Mt. Elgon constituency so that the Sabaots can have their own member of parliament to champion their grievances.

The Bukusu on the other hand accuse the Sabaot of alleniating themselves and identifying with the Kalenjin in the Rift Valley a fact that was always visible during elections where the Saboat voted to support the presidential candidate fronted by the Kalenjin community.

Table 6: Intermarriage among communities

\begin{tabular}{llll}
\hline & & Frequency & Percent \\
\hline \multirow{3}{*}{ Valid } & .00 & 2 & 2.2 \\
& Yes & 85 & 94.4 \\
& No & 3 & 3.3 \\
\hline & Total & $\mathbf{9 0}$ & $\mathbf{1 0 0 . 0}$
\end{tabular}

Communities in Bungoma County intermarry freely. 94.4\% of the sampled respondents indicated that there's free intermarriage among tribes residing in their Sub-Counties. A negligible 3.3\% responded to the contrary. However, this has done little to prevent conflict over land resource allocation in the County an indication that there is significant political undertones in the conflicts. 


\subsubsection{Frequency of conflict}

Table 7: Frequency of Conflict

\begin{tabular}{lll}
\hline & Frequency & Percent \\
\hline .00 & 3 & 3.3 \\
Fairly frequent & 14 & 15.6 \\
Valid Not frequent & 30 & 33.3 \\
Very Frequent & 2 & 2.2 \\
After every electoral cycle & 41 & 45.6 \\
& & \\
\hline Total & $\mathbf{9 0}$ & $\mathbf{1 0 0 . 0}$
\end{tabular}

The study also sought to establish the frequency of conflicts and as shown in Table 4.4.6, 45.6\% of the respondents reported that conflicts arise after every electoral cycle. $33.3 \%$ of the respondents said the conflicts though present, are not frequent while $15.6 \%$ of the sampled leaders said the conflicts are fairly frequent. In Kenya, elections are always associated with violence and it is not surprising that $45.6 \%$ of the sampled leaders in Bungoma County said the conflicts arise during and after elections. Politicians use violence to influence the outcome of elections.

The frequency of conflict especially around election time is an indication that politics is a major factor in the triggering of conflict in the County. Politicians take advantage of community grievances concerning land and distribution of development resources to whip up emotions and even sponsor violence for personal gain. In my discussion with leaders in the sampled sub- Counties it emerged that prior to elections the Sabaot leaders in $\mathrm{mt}$ Elgon cause tension to trigger mass exodus of the Bukusu so that they do not vote and tilt scales in favour of particular candidates.

\subsubsection{Adoption of negotiation in conflict resolution}

Negotiation has been overwhelmingly adopted as an alternative dispute resolution mechanism in Bungoma County. This is evidenced $93 \%$ confirmation by the sampled respondents. This question was aimed at establishing whether or not the leaders had adopted this mechanism in their day to day conflict resolution duties.

Table 8: Negotiation as used by leaders in dispute resolution

\begin{tabular}{|c|c|c|}
\hline & Frequency & Percent \\
\hline $\begin{array}{l}\text { 00 } \\
\text { any form of communication } \\
\text { back and forth communication } \\
\text { negotiators meet to work with or against } \\
\text { each other } \\
\text { negotiation proceedings take place } \\
\text { between groups of people } \\
\text { parties come to realization of the problem, } \\
\text { Valid ensure communication between confliciting } \\
\text { parties } \\
12.00 \\
15.00 \\
45.00 \\
56.00 \\
135.00 \\
145.00 \\
156.00 \\
1234.00\end{array}$ & $\begin{array}{l}6 \\
1 \\
1 \\
5 \\
1 \\
1 \\
1 \\
1\end{array}$ & $\begin{array}{l}2.2 \\
23.3 \\
8.9 \\
6.7 \\
1.1 \\
1.1 \\
5.6 \\
1.1 \\
1.1 \\
1.1 \\
1.1\end{array}$ \\
\hline Total & 90 & 100.0 \\
\hline
\end{tabular}


The purpose of negotiation is to engage the parties in dispute in direct communication that will result in a mutually agreed settlement of the dispute. The communication is usually back and forth and is designed to ensure the conflicting parties reach an agreement. This was pointed out by $17 \%$ of the sampled respondents. Mostly, negotiators meet to work with or against each other for their own position or pre-determined, desired outcomes. The aim is to extract as much as they can from the other party in the dispute.

Negotiation proceedings may take place between groups of people rather than individuals, and the list of tactics that negotiators may use is long and varied. Through negotiation both parties come to the realization that they have a problem, and both are aware that by talking to each other, they can find a solution to the problem. This was pointed out by $23 \%$ of the respondents.

Those leading the negotiations must ensure that there's communication between the conflicting parties intended to gain understanding, to produce agreement, to bargain between individual involved in a conflict or dispute.

In this study $24 \%$ of the sampled respondents indicated that the negotiation process they have adopted ensures that there's communication between the conflicting parties is intended to gain understanding and to produce a mutually agreeable settlement. $2 \%$ indicated that negotiations that take place are between groups of people rather than individuals. $4 \%$ of the respondents said negotiators meet to work with or against each other for their own position or pre-determined, desired outcome. They do this with the realization that they have a problem, and both are aware that by talking to each other, they can find a solution to the problem. It is clear from this study that the leaders pay a lot of attention to communication between the conflicting parties since this leads to understanding of each others' arguments and ultimately to a negotiated settlement.

1.9.5 Negotiation is based on the aggressive pursuit of interest by parties, is adversarial and competitive where parties make demands that are inconsiderate of the interest and needs of others

This study showed that a sizeable $47 \%$ of the respondents strongly agree that negotiation is based on the aggressive pursuit of interest by parties, and is typically adversarial and competitive where parties make demands that are inconsiderate of the interest and needs of others. The leaders pointed out that most times opposing sides in a dispute want to achieve their own interest and have little or no regard for their counterparts at the negotiating table. They mostly have the winner takes all mentality that mostly derails negotiations. It thus takes sober facilitation by neutral third parties to steer the negotiations through emphasis of give and take where parties are encouraged to strongly consider letting go off some demands to enable consensus building. $38 \%$ slightly agree with the above statement but were quick to point out that most disputants are not necessarily interested in seeing their counterparts lose in the negotiations but strongly work to avoid loss of what rightfully belongs to them. $13 \%$ of the sampled leaders strongly disagreed saying negotiations do not have to be adversarial and inconsistent with the needs of others. In land disputes for example they argued that historical boundaries are crucial in determining ownership and leaders call upon elders from time to time to unravel boundary disputes. What clear from the above graph is that negotiation is based on the aggressive pursuit of interest by parties, and is typically adversarial and competitive where parties make demands that are inconsiderate of the interest and needs of others.

1.9.6 The view that demands of one party can be met only to the detriment of the other where parties tend to stubbornly adhere to their positions and one side seems to dominate the negotiation.

In this study, $37 \%$ of the sampled respondents strongly agreed with the view that demands of one party can be met only to the detriment of the other where parties tend to stubbornly adhere to their positions and one side seems to dominate the negotiation. $39 \%$ of the leaders slightly agreed with this view while $22 \%$ of the respondents strongly disagreed with it.

This question was posed to the respondents to assess their understanding of negotiation and get a view of the kind of negotiation processes undertaken by these leaders in the course of their dispute resolution duties. Those who strongly agreed with the above statement were mostly from Lwandanyi and Cheptais Sub-Counties where land disputes abound. They mentioned that Sabaot and Bukusu were always motivated by ethnic rivalries and historical differences such that they had little regard for each other. 
Table 9: Opinion on negotiation processes

\begin{tabular}{llll}
\hline & & Frequency & Percent \\
\hline \multirow{2}{*}{ Valid } & Strongly agree & 44 & 48.9 \\
& Slightly agree & 31 & 34.4 \\
& Strongly disagree & 15 & 16.7 \\
\hline & & $\mathbf{9 0}$ & $\mathbf{1 0 0 . 0}$
\end{tabular}

In this study, $49 \%$ of the sampled respondents strongly agree with the view that in negotiation processes, the disputants may represent themselves or they may be represented by agents and whatever the case, they have control over the negotiation process.34\% of the respondents slightly agreed with this statement but did not give reasons why. $17 \%$ of the respondents strongly disagreed. Those who strongly agreed with this statement said land disputes attracted lawyers or advisor hired by disputants. This however was done by families that are endowed with resources. Those who come from poor backgrounds represented themselves but had control of the process.

\subsubsection{Level of acceptability of negotiation by the parties in resolving conflict}

In this study $77 \%$ of the sampled respondents said negotiation was highly acceptable among disputants in their areas of jurisdiction while $22 \%$ said they rarely used it. Negotiation is highly acceptable because it is cheap and is done in familiar surroundings. The leaders said Community elders know each other well and are able to access each other on short notice. The leaders i interviewed gave the example of 1992 land clashes between the Bukusu and the Sabaot in Cheptais Sub County where Community elders on both sides had to intervene to stop the killings after the failure of politicians to stop the fighting. The fighting was stopped through negotiations.

In Webuye Sub County a conflict was brewing between the Bukusu and the Tachoni following a proposal to review constituency boundaries. The Bukusu leaders were said to be opposed to the creation of a constituency for the Tachoni sub tribe but negotiations were held and the Tachoni got a constituency (Webuye North) for the first time since independence.

Table 10: Frequency of Recurrence of disputes addressed through Negotiation.

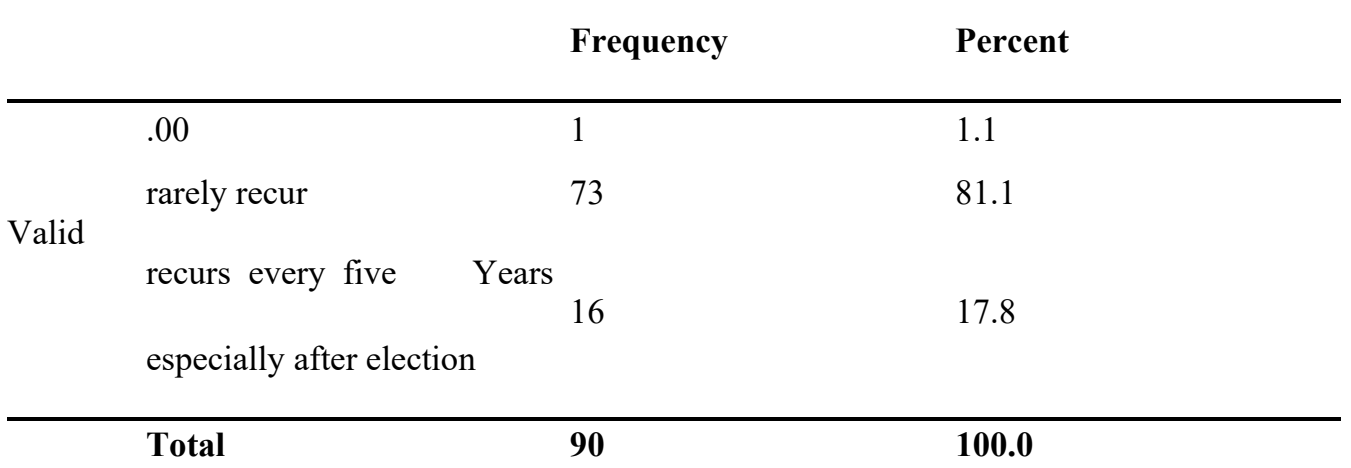

With regard to recurrence of disputes addressed through negotiation, $81 \%$ of the sampled leaders said that such disputes rarely recur while $18 \%$ said such disputes recur every five years especially during elections. Those who said the disputes rarely occur were however clear that such disputes are those land disputes between individuals and are far in between. Those who said the disputes recur every five years especially during elections made reference to community land disputes. These they said are common place between the Bukusu and the Sabaots in Cheptais and Lwandanyi Sub-Counties and are mostly fueled by politicians.

\subsubsection{Disputes resolved through negotiation}

According to the leaders sampled in this study, land disputes form the bulk of the disputes solved through mediation by leaders in the County accounting for $60 \%$ of the cases. Disputes over sharing of political leadership positions account for $9 \%$ of the cases while disputes arising out of unequal distribution of development resources only account for $10 \%$ of the cases. 
A further probe into why the land disputes featured prominently in cases handled by leaders through negotiation revealed that the County had huge chunks of land that had not been registered and lacked ownership title deeds. This the leaders said was the reason for the high number of land disputes. They blamed the lands ministry for this failure.

When asked why negotiation had taken center stage in land issues the leaders said residents were frustrated by court processes because they are slow but and costly. Disputes arising out of unequal distribution of development resources and sharing of state jobs were said to be handled by members of parliament and leaders in senior positions in government and only featured at the grassroots when members of parliament complain publicly at official functions to galvanize support and secure development support for the County.

\subsection{Conclusions}

Alternative dispute resolution mechanisms are an important component in the justice system of a country. They provide opportunity and space for parties in conflict to resolve the issues in contention amicably while avoiding the costs and delays associated with normal court processes.

This study established that though ADR mechanisms are in use at the community level, County governments have not put in place mechanisms to institutionalize ADR. There are glaring capacity gaps that continue to impact on the adoption and use of ADR mechanisms. This must be addressed.

\subsection{Recommendations.}

1. In order to address land disputes emanating from lack of clear ownership, the lands ministry needs to improve the quality-of-service delivery to the citizens of Bungoma County. Rampant corruption perpetuated by officers at the lands' office was cited as am major stumbling block in acquisition of land title deeds and must be stopped.

2. Land allocations in the former white settler areas of mt. Elgon have been infiltrated by political interests and this is the root cause of unrest in Mt. Elgon Sub-County. The national and County government must take decisive action to address the land grievances of the Sabaot community to stop the inter clan fighting that has led to loss of many lives and massive destruction of property.

3. For the leaders to be more effective in conflict resolution they must be trained and equipped with skills and competencies necessary for this responsibility. There's need to address the quality of the trainings being provided because they are poor.

4. The County government must invest in the establishment of arbitration structures at County level so that citizens can find assistance. This can be done through employment and training of arbitration personnel for the County.

\section{REFERENCES}

Algert, N.E. (1996). "Conflict in the workplace" in Proceedings: Women in Engineering Advocates Network, Denver, CO., 123-127.

Algert, N.E., and Watson, K. (2002). Conflict management: introductions for individuals and organizations. Bryan, TX.

Barrett, J. T., \& P. Barrett. J. P. (2004). A history of alternative dispute resolution: The story of a political, cultural, and social movement. Jossey-Bass A Wiley Imprint: San Francisco

Bennet, M. D., \& Hughes, S. (2005).The Art of Mediation (2nd ed.). N.p.: The National Institute for Trial Advocacy, INC.

Berg, W., \& Gall, M. (1989).Educational research: An introduction. New York: Longman

Bingham, L. B. (2004). Employment Dispute resolution: The case for mediation.Conflict Resolution Quartely,22(1-2), 145-174.

Bingham, L. B., \& Hallberlin, C. J. (2009). Dispute System Design and Justice in Employment Dispute Resolution: Mediation at the Workplace. Harvard Negotiation Law Review,14(1), 1-50

Blake, S., Browne, J., \& Stuart S. (2011). A practical approach to alternative dispute resolution. Oxford University Press Inc.: New York

Chesi, A. S. (2012). Factors influencing land related conflicts in MT. Elgon District, Bungoma County. Unpublished MBA thesis University of Nairobi.

Cooper, D.R., \& Schindler, P.S. (2000).Business Research Methods. 8th ed. New York, NY: McGraw-Hill.

Gill, J. and Johnson, P., (2002), Research Methods for Managers, 3rd. edn. , Sage, London

Ezeji, S.C.O.A. (1993). "An evaluation of relevance of technical education programme to job market needs. International Journals of Education Research. 5(6) 10-15

Fisher, R., \& William, U.(2011). Getting to yes: Negotiating agreement without giving In. Penguin Books ltd: London

Hornby A.S. (2006). Oxford Advanced Learner's Dictionary. India: Oxford University Press. 
Pamela L. A \& Robert B. S(1995). The survey research handbook, University of Wisconsin,Madison, 2nd edition,

Kothari, C. R. (2004), Research Methodology: Methods and Techniques. New Delhi:Wiley

Lacity, M., \& Jansen, M. A. (1994). Understanding qualitative data: A framework of text analysis methods. Journal of Management Information Systems, 11, 137-166.

Lambert, J., and Myers, S. (1999). 50 Activities for conflict resolution. Amherst, MA: HR Development Press.

Liebmann, M. (2000). Mediation in context. Jessica Kingsley Publishers Ltd: London.

Mnookin, R., Peppett, S.R., and Tulemello, A.S. (2000). Beyond Winning: Negotiating to Create Value in Deals and Disputes. Cambridge, MA: Harvard University Press. Chikwe, A. (2011). Learn when negotiating Behaviours is dynamic Pilot. University Lecturers skill enhancement training 2(2) 11-12.

David, J. F. (2006). Peace and conflict studies: An African Overview of Basic concepts.

Moore, C. W. (2003). The mediation process: Practical strategies for resolving conflict. 3rd Edition. Jossey-Bass: San Francisco

Mugenda,O.M and Mugenda, A.G. (2003). Research Methods, Quantitative \&Qualitative Approaches, African Centre For Technology Studies, ACTS press, Nairobi, Kenya pp

Mugenda. O. A. and Mugenda A. G. (1999). Research methods: Quantitative and Qualitative approaches, Nairobi, Act Press

Ngechu.M. (2004), Understanding the research process and methods.An introduction to research methods. Acts Press, Nairobi

Polkinghorne, D. (1988). Narrative knowing and the human sciences. Albany: State University of New York Press.

Otomar, J. B., and Wehr, P. (2001). Using Conflict theory. Press syndicate publishers. Newyork.

Ralf, D. (1958).Toward a Theory of Social Conflict. The Journal of Conflict Resolution, Vol. 2,No. 2. pp. 170183

Umunadi, E. K. (2011). The Efficacy Of Mediation and Negotiation Methods For Dispute Resolution In Delta State, Sacha Journal of Policy and Strategic Studies, Volume1Number 2, pp. 64-73

Uwazie, E. E. (2011). Alternative Dispute Resolution in Africa: Preventing Conflict and Enhancing Stability.African Security Brief, 1-6.

Zumeta, Z. (2000). Styles of mediation: Facilitative, evaluative, and transformative mediation'. 